\title{
PEMBELAJARAN PENDIDIKAN AGAMA ISLAM HUMANISTIK DENGAN PENDEKATAN ACTIVE LEARNING DI MTsN 1 BOMBANA
}

\author{
Agus Akmal \\ Nurman Said \\ Muhammad Khalifah Mustami
}

\begin{abstract}
Abstrak: Penelitian ini bertujuan untuk: 1) mengetahui pelaksanaan pembelajaran pendidikan agama Islam berbasis humanistik dengan pendekatan active learning di MTs Negeri 1 Bombana; 2) mengetahui hasil pembelajaran pendidikan agama Islam berbasis humanistik dengan pendekatan active learning di MTs Negeri 1 Bombana, 3) mengetahui kendala yang dihadap oleh siswa dan guru pada pembelajaran pendidikan agama Islam berbasis humanistik dengan pendekatan pembelajaran aktif (active learning) di MTs Negeri 1 Bombana.
\end{abstract}

Jenis penelitian ini adalah penelitian kualitatif dengan pendekatan penelitian yang digunakan adalah: pendekatan konstruktivisme, pendekatan saintifik, pendekatan realistik, dan pendekatan pedagogis. Adapun sumber data penelitian ini adalah: Kepala Madrasah, Wakil Kepala Madrasah, dewan guru, dan peserta didik. Metode pengumpulan data yang digunakan adalah observasi, wawancara, dan dokumentasi. Teknik pengolahan dan analisis data dilakukan tiga tahap, yaitu: reduksi data, paparan data, dan penarikan kesimpulan.

Hasil penelitian ini menunjukan bahwa implementasi pembelajaran PAI humanistik dengan pendekatan active learning, harus melalui tiga tahapan yakni: perencanaan, pelaksanaan, dan evaluasi. Untuk mengatasi berbagai kendala yang dihadapi, beberapa upaya yang yang harus dilakukan yakni melengkapi berbagai buku referensi atau buku penunjang pembelajaran, guru diberikan kesempatan untuk mengikuti kegiatan workshop atau pelatihan, paling tidak sesering mungkin bertukar pikiran dengan guru terkait pembelajaran PAI humanistik dengan pendetan active learning.

Implikasi dari penelitian ini adalah: 1) Pembelajaran PAI humanistik dengan pendekatan active learning, perlu dikembangkan terutama terkait implementasi pola pembelajaran PAI yang humanis; 2) Metode Pembelajaran PAI dengan pendekatan active learning harus lebih variatif agar siswa tidak merasa merima pelajaran dengan metode yang monoton. 3) Hasil pembelajaran PAI humanistik dengan pendekatan active learning, harus terpenuhi tiga ranah pendidikan yakni: ranah kognitif, ranah afektif dan ranah psikomotor. 4) Partisipasi orang tua pada kegiatan proses pembelajaran hendaknya sejalan dengan program pembelajaran yang 
diterapkan di sekolah terutama dalam pembelajaran PAI agar program pembelajaran tercapai sesuai yang diinginkan.

\section{Keywords: Humanistik; Pembelajaran Active Learning}

\section{PENDAHULUAN}

Pendidikan pada dasarnya merupakan upaya untuk mengarahkan anak didik ke dalam proses belajar sehingga menjadi yang terbaik sesuai dengan potensi yang mereka miliki. Menurut Abraham Maslow sebagaimana dikutip oleh Ahmad Jainuri bahwa pendidikan adalah proses "aktualisasi diri" (self actualization) meyakinkan bahwa setiap orang hendaknya berusaha merefleksikan semua yang bisa dilakukan dalam hidup. ${ }^{1}$ Dengan demikian pendidikan hendaknya memperhatikan kondisi individu anak karena merekalah yang akan belajar. Anak didik merupakan individu yang berbeda satu sama lain, memiliki keunikan masing-masing yang tidak sama dengan orang lain. Konsep humanistik mengajarkan manusia memiliki rasa kemanusiaan yang mendalam, menghilangkan sifat-sifat egoistis, otoriter dan individualitis. Tidak memaksakan lawan bicara untuk memahami, atau masuk dalam pebicaraan kita. Pendidikan humanistik adalah pendidikan yang memandang manusia sebagai manusia yakni mahluk hidup ciptaan Allah swt. dengan fitrah-fitrah tertentu untuk dikembangkan secara maksimal dan optimal.

Mengenai pendidikan humanistik atau konsep belajar humanstik tidak bisa dipisahkan dengan paham psikologi humanistik. Paham psikologi humanistik inilah yang diyakini oleh para ahli menjadi dasar atau sumber munculnya konsep pendidikan humanistik. Aliran ini selalu mendorong peningkatan kualitas diri manusia melalui penghargaannya terhadap potensi-potensi positif yang ada pada setiap insan. Seiring dengan perubahan dan tuntutan zaman, proses pendidikanpun senantiasa berubah. Dengan adanya perubahan dalam strategi pendidikan dari waktu ke waktu, humanistik memberikan arahan yang signifikan dalam pencapaian tujuan ini. ${ }^{2}$ Dalam prosesnya mereka diberi pengalaman belajar, diakui, diterima, dihargai, dan dimanusiakan, sehingga siswa menjadi optimis untuk sukses.

Teori humanistik dalam pembelajaran guru lebih mengarahkan siswa untuk berpikir induktif, mementingkan pengalaman, serta membutuhkan keterlibatan siswa secara aktif dalam proses belajar. Glasser berpendapat, hal ini dapat diterapkan melalui kegiatan diskusi, membahas materi secara berkelompok sehingga siswa dapat mengemukakan pendapatnya masing-masing di depan kelas. ${ }^{3}$ dalam konteks pembelajaran ini guru bertindak sebagai fasilitator. ${ }^{4}$ Dengan

\footnotetext{
${ }^{1}$ Ahmad Jainuri, "Membangun Karakter Pendidikan Muhammadiyah Yang Holistik dalam Edukasi, 1 April, 2010), h. 36-37.

${ }^{2}$ Ratna syifaa Rahmahana, Psikologi Humanistik dan Aplikasinya dalam Pendidikan, dalam El-Tarbawi: Jurnal Pendidikan Islam (http://Journal.Uji.ac.id/), hal. 16 diakses 23 maret 2012.

${ }^{3}$ Frank G. Goble, Mazhab Ketiga Psikologi Humanistik Abraham Maslow, ter. A. Supratiknya, (Yogyakarta: Kanisius, 1987), h. 261.

${ }^{4}$ Wasty Soemanto, Psikologi Pendidikan (Jakarta: Reinika Cipta, 2003), h. 233.
} 
tujuan membantu siswa untuk mengembangkan dirinya untuk mengenali diri mereka sendiri sebagai manusia yang unik dan membantu mewujudkan potensipotensi yang ada pada diri mereka. ${ }^{5}$

Banyak model pembelajaran humanistik yang telah diterapkan, termasuk experiential learning, dimana tujuan pembelajarannya adalah siswa memiliki keterampilan transfer of learning, sehingga diharapkan dapat mentransfer ilmu pengetahuan dalam kehidupan nyata. ${ }^{6}$ Experiential Learning mencakup beberapa model pembelajaran, salah satunya adalah active learning yang orientasinya lebih banyak menekankan pada keaktifan dan kemandirian siswa sebagai subjek dalam pembelajaran dan bertujuan mengaplikasikan apa saja yang baru mereka pelajari ke dalam satu persoalan dalam kehidupan nyata.

Pada dasarnya active learning adalah satu model pembelajaran yang melibatkan keaktifan siswa dan guru secara maksimal, guru hanya bertindak sebagai fasilitator, dan mengkontrol kegiatan pembelajaran siswa. Kemudian siswa sendiri berkompetisi diantara masing-masing untuk memperebutkan pemahaman yang sebenarnya atas materi yang diajarkan dan dimanifestasikan dalam kehidupan nyata. Sehingga model pembelajaran aktif termasuk salah satu dari beberapa bentuk pembelajaran yang humanistik ${ }^{8}$, dengan pembelajaran aktif peserta didik mampu menggali potensi yang dimiliki untuk menjadi manusia yang otentik.

Tidak mudah dalam menentukan pendekatan dan model pembelajaran, apalagi belum seluruh pendekatan dan model pembelajaran dapat menciptakan manusia sebagai manusia yang sesungguhnya, meskipun berbagai pendekatan, strategi dan model pembelajaran telah banyak diterapkan dalam proses pembelajaran. Hal itu disebabkan, masih banyak bentuk atau model yang diterapkan dalam proses pembelajaran dengan tujuan sekedar mentransfer pengetahuan saja, sehingga menghasilkan kualitas pembelajaran masih dalam tingkat kognitif. Akibatnya menghasilkan pula pengalaman belajar yang kurang dipahami dan bermakna, untuk diterapkan dalam kehidupan nyata.

Lain halnya pembelajaran Pendidikan Agama Islam di MTs Negeri 1 Bombana, pembelajaran aktif adalah salah satu upaya untuk menggali potensi yang ada dalam diri peserta didik yang diaktualisasikan dalam bentuk tanya jawab, diskusi, praktik serta demonstrasi dan beberapa pembelajaran aktif lainnya. Sehingga peserta didik mampu memahami materi dari sebuah proses belajar, dimana dalam proses belajar tersebut mereka sebagai subyek belajar (students center). Selanjutnya dari pengetahuan yang didapat dari proses belajar tersebut diterapkan dalam kehidupan sehari-hari. Dalam posisi ini, guru bertindak sebagai fasilitator atau rekan yang telah berpengalaman.

\footnotetext{
${ }^{5}$ Wasty Soemanto, Psikologi Pendidikan, h. 136.

${ }^{6}$ Esa Burhanuddin dan Nur Wahyuni, Teori Belajar dan Pembelajaran, (Yogyakarta: ArRuzz Media, 2010), h. 164.

${ }^{7}$ Hisyam Zaini, dkk, Strategi Pembelajaran Aktif (Yogyakarta: Pustaka Insan Madani, 2008), h.14.

${ }^{8}$ Sahaka Emporium, Pendekatan Pembelajaran Humanistik, http://sahaka.multiply.com/journal/item/10/Pendekatan_Pembelajaran_Humanistik, (diakses tanggal 10 September 2017)
} 
Model pembelajaran Pendidikan Agama Islam yang dilakukan di MTsN 1 Bombana menunjukkan sebuah proses pembelajaran yang mengarah pada teori pembelajaran humanistik. Pembelajaran humanistik menutut adanya keaktifan siswa dalam proses pembelajaran, oleh karena itu siswa tidak menjadi penerima pasif dalam proses pembelajaran. Dengan model pembelajaran aktif siswa merasa senang, bergairah, berinisiatif dalam belajar dan terjadi perubahan pola pikir, perilaku dan sikap atas kemauan sendiri. Siswa diharapkan mampu menjadi manusia yang bebas, tidak terikat oleh pendapat orang lain dan mengatur pribadinya sendiri dan bertanggung jawab tanpa mengurangi hak-hak orang lain atau melanggar aturan, norma, disiplin atau etika yang berlaku.

Fokus penelitian adalah Pembelajaran Pendidikan Agama Islam Humanistik dengan Pendekatan active learning di MTsN 1 Bombana. Sedangkan yang menjadi deskripsi fokus adalah:

a. Pembelajaran PAI yang humanistik adalah suatu proses pembelajaran pendidikan Agama Islam dalam pentransferan ilmu pengetahuan dari guru kepada siswa dengan cara yang humanistik (memanusiakan manusia).

b. Pembelajaran PAI dengan pendekatan Active Learning adalah suatu proses belajar mengajara Pendidikan Agama Islam dengan menggunakan pendekatan pembelajaran aktif.

Berdasarkan fokus dan deskripsi tersebut di atas, maka persoalan pokok dalam penelitian ini adalah Bagaimana Pembelajaran Agama Islam Humanistik dengan pendekatan active learning di MTsN 1 Bombana Kecamatan Kabaena Kabupaten Bombana Propinsi Sulawesi Tenggara. Pada pokok tersebut dikembangkan dalam beberapa sub masalah sebagai berikut: 1) Bagaiamana Pelaksanaan pembelajaran Pendidikan Agama Islam humanistik dengan pendekatan active learning di MTs Negeri 1 Bombana? 2) Bagaimana hasil pembelajaran Pendidikan Agama Islam humanistik dengan pendekatan active learning di MTs Negeri 1 Bombana?. 3) Bagaimana kendala bagi siswa dan guru pada pembelajaran Pendidikan Agama Islam humanistik dengan pendekatan active learning di MTs Negeri 1 Bombana?

\section{TINJAUAN TEORETIS}

Agus Basri Mengatakan bahwa: Pendidikan agama islam adalah bimbingan jasmani dan rohani yang berdasarkan ajaran Islam menuju terwujudnya suatu kepribadian yang utama yang integral, terpadu dan harmonis secara islam. ${ }^{9}$ Sedangkan menurut Zuhairini, pendidikan agama Islam adalah usaha sadar untuk membimbing kearah pembentukan kepribadian peserta didik secara sistematis dan pragmatis, supaya hidup sesuai dengan ajaran agama Islam, sehingga terjadinya kebahagiaan dunia ahirat. ${ }^{10}$ Dari kedua pengertian pendidikan agama Islam tersebut dapat dipahami bahwa pendidikan agama Islam itu orientasinya mengarah kepada dua hal yaitu jasmani dan rohani atau lahir dan batin.

\footnotetext{
${ }^{9}$ Agus Basri, Pendidikan Islam sebagai Penggerak Pembaharuan (Cet. I; Bandung: PT. Al Ma'rif, 1984), h. 22.

${ }^{10}$ Zuhairini, Metodologi Pembekajaran Pendidikan Agama Islam, (Malang: UIN Malang Press, 2004), h. 11.
} 
Humanistik adalah aliran dalam psikologi yang muncul tahun 1950-an sebagai reaksi terhadap behaviorisme dan psikoanalisis. Aliran ini secara eksplisit memberikan perhatian pada dimensi manusia dari psikologi dan konteks manusia dalam pengembangan teori psikologis. ${ }^{11}$ Secara etimologis humanistik berarti isme atau aliran tentang manusia. Humanistik dapat juga diterjemahkan sebagai "manusiaisme". Dalam arti luas humanistik adalah suatu konsep tentang manusia sebagai pusat eksistensi. Sebagaima sesuatu yang ada menjadi tak berarti kalau bukan untuk dan demi manusia. ${ }^{12}$ Dalam dunia pendidikan banyak dikenal beberapa teori pendidikan. Salah satunya yaitu teori humanistik yang fokus pembahasanya menitikberatkan kepada perilaku seseorang manusia. Pada hakikatnya teori ini berkembang dari aliran psikologi yang kemudian berpengaruh terhadap arah pengembangan teori, praktek pendidikan dan pembelajaran yang dikenal sebagai aliran humanistik. Oleh karena itu prespektif disiplin ilmu yang digunakan dalam menyusun tesis ini yaitu bagaimana seorang pendidik dalam menerapkan proses pembelajaran sesuai dengan teori humanistik. Dalam teori belajar humanistik, belajar dianggap berhasil jika peserta didik memahami lingkungannya dan dirinya sendiri. Siswa dalam proses belajarnya harus berusaha agar lambat laun mampu mencapai aktualisasi diri dengan sebaik-baiknya.

Kata active diadopsi dari bahasa inggris dengan kata sifat yang aktif, gesit, giat, bersemangat. ${ }^{13}$ Dan learning berasal dari kata learn yang berarti mempelajari. ${ }^{14}$ Dari dua kata tersebut yaitu active dan learning dapat diartikan dengan mempelajari sesuatu dengan active atau bersemangat dalam hal proses pembelajaran.

Konsep active learning atau cara belajar siswa aktif, dapat diartikan sebagai penganut pembelajaran yang mengarah pada pengoptimalisasian pelibatan intelektuan dan emosional siswa dalam proses pembelajaran, diarahkan untuk membelajarkan siswa, bagaimana belajar memperoleh dan memproses perolehan belajarnya tentang pengetahuan, ketrampilan, sikap dan nilai. ${ }^{15}$ Pada hakekatnya konsep active learning adalah untuk mengembangkan keaktifan proses pembelajaran baik dilakukan oleh guru ataupun siswa. pada active learning tampak jelas kalau guru aktif mengajar dan siswa aktif belajar. Konsep ini sesuai dengan konsep kurikulum K-13, walaupun dalam implementasinya masih banyak ditemukan berbagai kendala dan hambatan.

\section{III.KERANGKA KONSEPTUAL}

Pendidikan Agama Islam sangat di perlukan dalam proses pembelajaran di sekolah, mengingat tingkah laku peseeta didik sangat dinamis dari waktu kewaktu. Tingkah laku dan perbuatan peserta didik selalu berubah. Oleh sebab itu

\footnotetext{
${ }^{11}$ Bambang Sugiharto, ed., Humanisme dan Humaniora (Bandung: Pustaka Matahari, 2013), h. 18.

${ }^{12}$ Bambang Sugiharto, ed., Humanisme dan Humaniora, h. 169.

${ }^{13}$ John M. Echols dan Hassan Sadhily, Kamus Inggris Indonesia (Jakarta: Gramedia, 1998), h. 9.

${ }^{14}$ John M. Echols dan Hassan Sadhily, Kamus Inggris Indonesia, h. 352

${ }^{15}$ Mudjiono Dimyati, Belajar dan Pembelajaran (Jakarta: PT. Rineka Cipta, 1999), h.

115.
} 
suasana kelas harus selalu di isi dengan pembelajaran Agama untuk mengontrol prilaku, perbuatan, sikap dan emosional peserta didik. Pembelajaran Agama merupakan upaya untuk mengontrol perilaku siswa secara optimal, agar siswa tidak terjerumus pada permasalahan sosial yang tidak sesuai ajaran Agama, sekaligus untuk mendukung interaksi edukatif dalam mencapai tujuan pembejaran. Dalam hal ini guru adalah pihak yang berperan utama dalam tugas pembelajaran dikelas. Dengan pembelajaran Agama yang baik diharapkan tercipta suasana dan kondisi belajar yang kondusif, sehingga harapan peserta didik dapat menguasai kompetensi di bidang agama sesuai denga tujuan belajar yang akan bermuara pada pencapaian prestasi belajar.

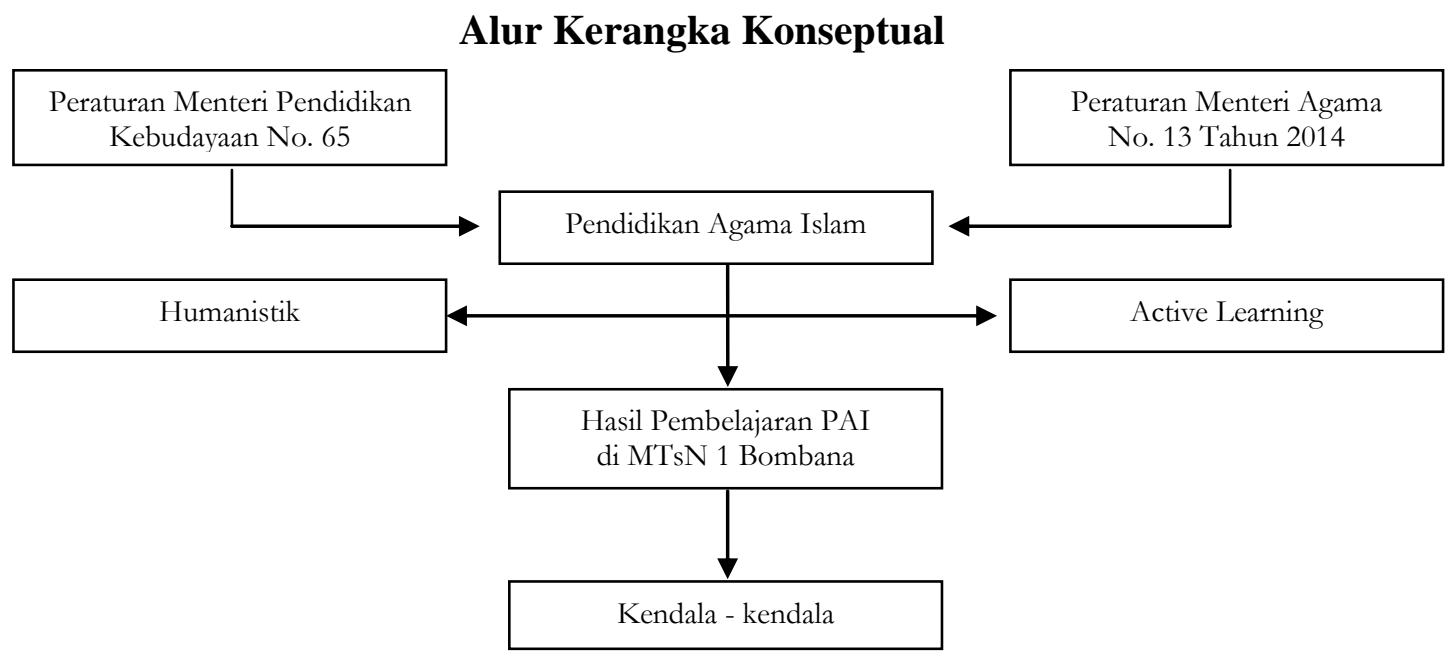

\section{METODOLOGI PENELITIAN}

Jenis penelitian ini merupakan penelitian lapangan (feald reasech) dengan menggunakan metode kualitatif. Penelitian kualitatif dalam penelitian ini adalah mengungkap secara faktual dan sistematis mengenai pelaksanaan pembelajaran agama Islam humanistik dengan pendekatan active learning di MTsN 1 Bombana. Selain itu dapat juga membahas Hasil Pembelajaran Agama Islam humanistik dengan pendekatan active learning di MTsN 1 Bombana. Mengungkap yang menjadi kendala-kendala yang dihadap oleh siswa dan guru pada Pembelajaran Pendidikan Agama Islam humanistik dengan pendekatan active learning di MTsN 1 Bombana Kabupaten Bombana Provinsi Sulawesi Tenggara.

Pendekatan yang digunakan dalam penelitian ini adalah: 1) Konstruktivisme yaitu pembelajaran yang bersifat generatif, yaitu tindakan menciptakan sesuatu makna dari apa yang di pelajari. Pendekatan konstruktivisme mempunyai beberapa konsep umum seperti belajar aktif, membina pengetahuan, berasaskan pengalaman yang sudah ada. 2) Pendekatan saintific, dalam kurikulum baru perubahan yang mempengaruhi pola pikir yaitu pembelajaran disusun seimbang mencakup kompetensi kognitif, afektif dan psikomotor. 3) Pendekatan realistic adalah suatu pendekatan yang dilakukan oleh guru terhadap siswa dengan menampilkan hal-hal yang nyata, dan sesuai karakteristik mata pelajaran yang diajarkan. Pendekatan realistik lebih menampilkan model pembelajaran yang 
nyata berdasarkan kenyataan yang dihadapi siswa. 4) Pendekatan pedagogis, yaitu pendekatan yang beranjak dari konsep dan teori pendidikan. Data yang diproleh dari sumber rujukan dan hasil penelitian akan dianalisis dengan menggunakan pendekatan pedagogis yang bertujuan untuk menemukan keterkaitan data tersebut dengan konsep pendidikan yang ada.

Sumber data yang diperoleh terdiri atas dua, yakni data primer dan sekunder. Data primer yang bersumber dari penelitian lapangan yang disebut field research. Data primer yang bersumber dari informan yang terdiri dari guru, siswa, staf atau pekerja jasa dan profesi lainnya. Data sekunder yakni temuan data dari berbagai kajian literatur pustaka yang disebut library research yang diperoleh dengan cara mencari kata kunci melalui katalog dan indeks. Selanjutnya mencari data melalui bilbliografi yang diterbitkan dalam tema khusus.

Untuk memperoleh data, fakta dan informasi yang dapat mengungkapkan serta menjelaskan permasalahan, penulis menggunakan: a) metode observasi dilakukan di MTs Negeri 1 Bombana yang sedang berlangsung selama 3 bulan; b) metode interview ditujukan kepada guru, Kepala Sekolah, siswa-siswi MTsN 1 Bombana serta staf di sekolah tersebut; c) metode dokumentasi dilakukan dengan cara mencari data melalui Silabus, Rencana Pelaksanaan Pembelajaran (RPP), daftar nilai, hasil karya atau rangkuman siswa dan dokumen-dokumen resmi sekolah serta dokumen yang berkaitan dengan penelitian ini.

Instrumen merupakan alat bantu yang digunakan dalam melaksanakan penelitian yang disesuaikan dengan metode yang digunakan. Dalam penelitian ini peneliti menggunakan beberapa jenis intrumen yaitu: Peneliti sendiri yang berfungsi sebagai intrumen yang dapat berinteraksi terhadap lingkungan penelitian, dan pedoman observasi. adalah alat bantu berupa pedoman pengumpulan data yang digunakan pada saat proses penelitian, serta pedoman wawancara. adalah alat berupa catatan-catatan pertanyaan atau pernyataan yang digunakan dalam mengumpulkan data dan alat-alat lainnya.

Setelah data terkumpul melalui observasi, wawancara dan analisis dokumen, maka selanjutnya menganalisis data-data tersebut. Adapun teknik analisis yang digunakan adalah teknik analisis data kualitatif, menggunakan model analisis interaktif. Dalam hal ini peneliti menggunakan teknik jenis triangulasi metode digunakan untuk data atau informasi yang diperoleh dari subjek atau informan penelitian yang diragukan kebenarannya., sedangkan triangulasi sumber dimanfaatkan untuk menggali kebenaran informasi tertentu melalui berbagai metode dan sumber perolehan data.

Uji keabsahan data dalam penelitian kualitatif meliputi: a) Kredibilitas, Pengecekkan kredibilitas atau derajat kepercayaan data perlu dilakukan untuk membuktikan apakah yang diamati oleh peneliti benar-benar sesuai dengan apa yang sesungguhnya terjadi secara wajar dilapangan; b) Transferabilitas, dengan cara "uraian rinci". Untuk kepentingan ini peneliti berusaha melaporkan hasil penelitiannya secara rinci. Uraian laporan diusahakan dapat mengungkapkan secara khusus segala sesuatu yang diperlukan oleh pembaca, agar pembaca dapat memahami temuan-temuan yang diperoleh. Penemuan itu sendiri bukan bagian dari uraian rinci melainkan penafsirannya diuraikan secara rinci dengan penuh tanggung jawab berdasarkan kejadian-kejadian nyata; c) Dependabilitas, 
dilakukan untuk menanggulangi kesalahan-kesalahan dalam konseptualisasi rencana penelitian, pengumpulan data, inteprestasi temuan, dan pelaporan hasil penelitian. Untuk diperlukan dependent auditor. Sebagai dependent auditor dalam penelitian ini adalah para pembimbing; d) Konfirmabilitas, dalam penelitian ini dilakukan bersama-sama dengan pengauditan dependabilitas. Perbedaannya, pengauditan konfirmabilitas digunakan untuk menilai hasil (product) penelitian, sedangkan pengauditan dependabilitas digunakan untuk menilai proses (process) yang dilalui peneliti dilapangan. Inti pertanyaan pada konfirmabilitas adalah: apakah keterkaitan antara data, informasi, dan interprestasi yang dituangkan dalam organisasi pelaporan didukung oleh materi-materi yang tersedia atau digunakan dalam audit trail ${ }^{16}$

\section{HASIL PENELITIAN DAN PEMBAHASAN}

\section{A. Hasil Penelitian}

1. Pelaksanaan Pembelajaran Pendidikann Agama Islam Humanistik dengan pendekatan Active Learning.

Esensi dari pendidikan adalah adanya transfer nilai pengetahuan dan keterampilan dari generasi tua kepada generasi muda agar generasi muda mampu hidup layaknya manusia umumnya.

Menurut Lukman, konsep pelaksanaan Pendidikan Agama Islam humanistik merupakan usaha pendidik menerapkan pembelajaran agama Islam menempatkan manusia sebagai manusia, sebagaimana cara pandang ajaran agama Islam itu sendiri. Dalam penerapannya pula suatu usaha humanisasi ilmu-ilmu pengetahuan dengan penuh keimanan yang disertai dengan hubungan manusia dengan Allah swt. dan hubungan manusia dengan manusia atau Hablun min Allah dan hablun min al-nas. ${ }^{17}$

Uraian dari informan tersebut, dapat disimpulkan bahwa pembelajaran pendidikan agama Islam humanistik adalah proses pebelajaran untuk mengembangkan potensi yang berorientasi pada manusia seutuhnya dengan memperhatikan aspek tanggung jawab hubungan dengan manusia dan hubungan dengan Allah swt., sehingga memiliki kekuatan spirituan keagamaan, kesalehan individu, yang diperlukan oleh diri, msyarakat, bangsa dan negara serta terciptanya suatu proses dan pola pendidikan yang senantiasa menempatkan manusia sebagai manusia, yaitu manusia yang memiliki segala potensi yang berupa fisik, psikis maupun spiritual, yang perlu mendapatkan bimbingan.

Pembelajaran Pendidikan agama Islam dengan pendekatan active learning dalam implementasinya harus dimulai dari perncanaan, pelaksanaan, dan evaluasi.

a) Perencanaan Pembelajaran PAI pendekatan active learning.

b) Pelaksanaan Pembelajaran PAI pendekatan active learning.

c) Evaluasi Pembelajaran PAI pendekatan active learning.

Konsep pelaksanaan pembelajaran pendidikan Agama Islam humanistik dengan pendekatan active learning di MTsN 1 Bombana, lebih menekankan pada aktifitas guru yang humanis dengan menggunakan pendekatan active learning,

\footnotetext{
${ }^{16}$ Sugiyono, Memahami Penelitian Kualitatif (Bandung: Alfabet, 2005), h. 117-131.

${ }^{17}$ Lukman (52 tahun), Kepala Madrasah Tsanawiyah Negeri 1 Bombana, Wawancara, Teomokole, 21 Maret 2018.
} 
sehingga kemampuan siswa diharapkan mampu mngembangkan potensi yang dimilikinya. Oleh karena itu, siswa diharapkan aktif dalam proses pembelajaran dengan mengedepankan sikap guru yang humanis, agar tercapainya tujuan pembelajaran.

2. Hasil Pembelajaran Pendidikan Agama Islam Humanistik dengan Pendekatan Active Learning.

Pembelajaran agama Islam humanistik dengan pendekatan Active Learning di MTsN 1 Bombana terpenuhi tiga aspek tujuan pembelajaran yaitu aspek kognitif, afektif dan psikomotor. Tiga aspek inilah yang menjadi tolok ukur keberhasilan dalam proses pembelajaran. Aspek kognitif berorientasi pada kemampuan berfikir yang mencakup kemampuan intelektual yang lebih sederhana yaitu mengingat sampai pada kemampuan memecahkan masalah yang menuntut siswa untuk menghubungkan dan menggabungkan beberapa ide, gagasan, metode atau prosedur yang dipelajari untuk memecahkan masalah tersebut. Aspek Afektif adalah untuk mengetahui capaian hasil belajar dalam hal penguasaan domain afektif dari kompetensi yang diharapkan dikuasai oleh setiap siswa, setelah kegiatan pembelajaran berlangsung. Aspek psikomotorik mencakup persiapan, proses, dan produk. Persiapan dapat dilakukan pada saat proses berlangsung yaitu pada waktu siswa melakukan praktik, atau sesudah proses berlangsung atau sesudah proses pembelajaran berlangsung dengan cara mengevaluasi hasil kerja siswa.

Berdasarkan nilai raport semester ganjil tahun pelajaran 2017/2018 pada mata pelajaran Pendidikan Agama Islam yakni mata pelajaran Fiqih, Aqidah Akhlaq, Sejarah Kebudayaan Islam, Qur'an Hadits dan Bahasa Arab, adalah:

a. Ranah Kognitif

Dari lima mata pelajaran Pendidikan Agama Islam, nilai rata-rata kognitif menunjukkan bahwa mata pelajaran Sejarah Kebudayaan Islam dan Qur'an Hadits lebih baik tingkat pemahaman siswa dibandingkan dengan mata pelajaran Pendidikan Agama Islam lainnya.

b. Psikomotorik

Dari lima mata pelajaran pendidikan agama Islam, nilai rata-rata psikomotorik menunjukkan bahwa mata pelajaran Fiqih dan Qur'an Hadits lebih baik tingkat pemahaman siswa dibandingkan dengan mata pelajaran pendidikan agama islam lainnya.

c. Afektif

Dari lima mata pelajaran pendidikan agama Islam, nilai rata-rata afektif menunjukkan bahwa mata pelajaran Fiqih lebih baik tingkat pemahaman siswa dibandingkan dengan mata pelajaran pendidikan agama Islam lainnya.

Berdasarkan ketiga nilai tersebut yang menjadi tolok ukur kemampuan siswa dalam evaluasi hasil belajar menunjukkan guru mata pelajaran fiqih lebih baik dari guru mata pelajaran pendidikan agama Islam lainnya, yang lebih menekankan pada sikap (afektif) dan kemampuan bertidak/ketrampilan (psikomotorik). Sedangakan pada mata pelajaran Sejarah Kebudayaan Islam dan lebih menekankan pada kemampuan pengetahuan (kognitif) berupa kemampuan menghafal atau mengingat apa yang telah diajarkan oleh guru. Walaupun demikian jika dilihat dari hasil capaian nilai secara klasikal di lima mata pelajaran 
Pendidikan Agama Islam tersebut, masih di atas nilai kriteria ketuntasan minimum dan siswa dinyatakan tuntas.

3. Kendala Pembelajaran Pendidikan Agama Islam Humanistik dengan Pendekatan Active Learning.

Fenomena yang terlihat dikehidupan saat ini memang masyarakat membutuhkan pribadi-pribadi yang handal dalam bidang akademis, ketrampilan dan keahlian dan sekaligus memiliki watak yang baik. Atau lebih jelasnya pribadi yang cerdas, berkeahlian namun tetap humanis. Banyak orang terlihat cerdas namun tidak kooperatif terhadap sesamanya, cenderung memilih siapa dan dimana dia bergaul, meremehkan orang lain, menganggap dirinya lebih, hingga kemudian tidak sadar akan kelebihan orang disekitarnya. Dari pembelajaran agama Islam humanistik dengan pendekatan active learning di MTsN1 Bombana tentu tidak selamanya berjalan mulus seperti yang diharapkan terutama saat sedang terjadi proses pembelajaran. Penerapan proses pembelajaran pendidikan agama Islam humanistik dengan pendekatan active learning tentu tidak terlepas dari berbagai kendala, yang menjadi kendala-kendala pembelajaran pendidikan agama Islam humanistik dengan pendekatan active learning di MTsN 1 Bombana adalah:

a. Siswa

Kendala-kendala yang dialami siswa dalam proses pembelajaran PAI humanistik dengan pendekatan active learning adalah: 1) Kurangnya minat siswa terhadap mata pelajaran pendidikan agama Islam; 2) faktor guru yang menjadikan siswa enggan mengikuti proses belajar mengajar terhadap mata pelajaran pelajaran pendidikan agama Islam; 3) Terbatasnya sumber ajar berupa buku, modul, serta sumber bacaan lain yang menjadi sumber bacaan terhadap mata pelajaran pelajaran pendidikan agama Islam.

b. Guru

Kendala-kendala yang dialami guru dalam proses pembelajaran PAI humanistik dengan pendekatan active learning adalah: 1) Terbatasnya kemampuan guru PAI dalam menerapkan metode pembelajaran active learning; 2) Terbatasnya pemanfaatan metode pembelajaran active learning oleh sejumlah guru pendidikan agama Islam; 3) Keterbatasan kemampuan guru dalam menguasai materi yang diajarkan karena tidak sesuai dengan kompetensi yang dimilikinya; 4) Kurangnya penguasaan teknologi informasi (TI) oleh sebagian guru, sehingga dalam pengelolaan proses pembelajaran tidak maksimal.

\section{B. Pembahasan}

MTsN 1 Bombana adalah sekolah yang bercirikan Islam. Jika di sekolah umum seperti SMP mata pelajaran agama hanya satu sebutan yakni mata pelajaran agama dan diajarkannya pun secara umum. MTsN 1 Bombana khususnya, mata pelajaran agama dipecah menjadi 5 yakni: 1) Mata pelajaran fiqih, 2) mata pelajaran Aqidah Akhlaq, 3) Mata pelajaran Al-Qur'ān Hadits, 4) Mata Pelajaran Sejarah Kebudayaan Islam dan 5) Mata Pelajaran Bahasa Arab.

Untuk mewujudkan hal tersebut, MTsN 1 Bombana dalam pelaksanaan Pembelaran Pendidikan Agama Islam humanistik dengan pendekatan active learning, menerapkan beberapa metode yang dapat digunakan di lima mata 
pelajaran Agama Islam yang terdiri dari Fiqih, Aqidah Akhlaq, Sejarah Kebudayaan Islam, Al-Qur'ān Hadits dan Bahasa Arab dengan pembelajaran yang Aktif, Inovatif, Kretif, Evektif, Menyenangkan, dan Islami (PAIKEMI). Adapun contoh dalam penerapan metode yang dapat digunakan pada mata pelajaran fiqih diantaranya:

Untuk mata pelajaran Fiqih dalam penerapan proses pembelajaran ada beberapa metode yang cocok digunakan antara lain:

1. Metode diskusi. Diskusi adalah kegiatan kelompok dalam memecahkan masalah untuk mengambil kesimpulan. Diskusi berbeda dengan berdebat. Diskusi selalu diarahkan kepada pemecahan masalah yang dari hasil diskusi tersebut menimbulkan beberapa macam pendapat dan akhirnya diambil suatu kesimpulan yang dapat diambil oleh semua kelompok. Pencapaian dalam penggunaan metode diskusi adalah siswa lebih aktif, inovatif, efektif, menyenangkan dengan tutur kata yang islami.

2. Metode tanya jawab. Satu teknik mengajar yang dapat membantu kekurangan yang terdapat pada metode ceramah. Metode tanya jawab ini dilakukan oleh guru karena sudah memperoleh gambaran sejauh mana siswa dapat mengartikan dan mengungkapkan apa yang telah diceramahkan. Pencapaian dalam penggunaan metode tanya jawab adalah siswa lebih aktif, kreatif, efektif.

3. Metode demonstrasi. Metode demonstrasi adalah metode yang sangat sederhana dibandingkan metode mengajar lainya. Metode demonstrasi adalah pertunjukan tentang proses terjadinya suatu peristiwa atau benda sampai pada penampilan tingkah laku yang dicontohkan agar dapat dipahami dan diketahui oleh siswa lainnya. Pencapaian dalam penggunaan metode demonstrasi adalah siswa lebih aktif, inovatif, kreatif, dan menyenangkan.

Metode tersebut adalah metode yang memiliki unsur humanis. dalam penerapannya disesuaikan dengan materi yang akan diajarkan. Sehingga siswa dapat menyiapkan mental untuk menghadapi metode yang akan digunakan oleh guru.

Berdasarkan hasil wawancara, penerapan pembelajaran untuk mata pelajaran fiqih selama ini, banyak metode yang diterapkan, namun metode tersebut lebih kelihatan hasilnya ketimbang metode caramah. Metode tersebut melibatkan peran siswa dalam mengaplikasikan teori yang telah diberikan sebelumnya.

Tolok ukur pembelajaran Pendidikan Agama Islam yang humanis adalah:

1. Pola interaktif yang bermartabat.

2. Sanksi yang memanusiakan

3. Pembelajaran Agama Islam tanpa ancaman

Hasil belajar yang baik ditunjukkan oleh nilai ujian yang tinggi merupakan indikator dari proses belajar mengajar yang baik, hasil belajar juga merupakan patokan berhasil tidaknya siswa dalam proses pembelajaran. Dalam mencapai hasil belajar yang baik, selain perlu penguasaan materi juga harus didukung dengan adanya interaksi multi arah antara pendidik dan siswa maupun antara siswa yang satu dengan yang lainnya. Dengan demikian hasil observasi dalam penelitian ini dapat disimpulkan bahwa proses pembelajaran di kelas sangat baik 
karena dalam proses pembelajaran antara pendidik dan siswa terjalin komunikasi yang baik. Dalam kurun empat tahun terakhir sejak pemerintah memberlakukan kurikulum 2013 yang umumnya dunia pendidikan menyebutnya dengan K 13, di MTs Negeri 1 Bombana sudah menerapkan kurikupum 2013 secara bertahap. Oleh karena itu, MTsN 1 Bombana dalam menerapkan kurikulum 2013 ini membuat tiap mata pelajaran lebih diminati oleh siswa.

Adapun hasil pembelajaran pendidikan agama Islam humanistik dengan pendekatan active learning yang telah dicapai dalam tujuan pembelajaran yaitu aspek kognitif, afektif, dan psikomotorik.

1. Aspek kognitif

Dari lima mata pelajaran pendidikan agama Islam, nilai rata-rata kognitif menunjukkan bahwa mata pelajaran sejarah kebudayaan islam dan Qur'an Hadits lebih baik tingkat pemahaman siswa dibandingkan dengan mata pelajaran pendidikan agama islam lainnya.

2. Psikomotorik.

Dari lima mata pelajaran pendidikan agama Islam, nilai rata-rata psikomotorik menunjukkan bahwa mata pelajaran Fikih dan Qur'an Hadits lebih baik tingkat pemahaman siswa dibandingkan dengan mata pelajaran pendidikan agama islam lainnya.

3. Afektif

Dari lima mata pelajaran pendidikan agama Islam, nilai rata-rata afektif menunjukkan bahwa mata pelajaran Fikih lebih baik tingkat pemahaman siswa dibandingkan dengan mata pelajaran pendidikan agama Islam lainnya.

Berdasarkan gambaran tiga ranah tersebut, dapat dilihat bahwa setiap mata pelajaran PAI di MTsN 1 Bombana telah memenuhi ketiga aspek penialaian yang dimaksudkan, oleh karena itu diaharapkan kedepannya yang diperhatikan oleh guru adalah ktuntasan ketiga nilai aspek penilaian yakni penilaian aspek kognitif, psikomotorik dan afektif sesuai dengan kurikulum 2013.

Nilai yang diperoleh secara kelas menunjukan kurangnya siswa yang menjalani remedial, ini semua tidak terlepas dari proses pembelajaran yang menyenangkan dan bersifat humanis. Dengan demikian jika dipersentase capaian kelulusan dalam pelaksanaan ujian semester ganjil, dapat mencapai di atas $90 \%$ dan semua ini tidak terlepas dari peran guru dalam membina dan membimbing peserta didik dalam proses pembelajaran.

Pembelajaran Pendidikan Agama Islam humanistik dengan pendekatan Active Learning di MTsN 1 Bombana tentu tidak selamanya berjalan mulus seperti yang diharapkan terutama saat sedang terjadi proses pembelajaran. Penerapan proses pembelajaran pendidikan agama Islam humanistik dengan pendekatan active learning tentu tidak terlepas dari berbagai kendala.

Kendala-kendala pembelajaran Pendidikan Agama Islam humanistik dengan pendekatan active learning di MTsN 1 Bombana adalah:

1. Siswa

Kendala-kendala yang dialami siswa dalam proses pembelajaran PAI humanistik dengan pendekatan active learning adalah:

a) Kurangnya minat siswa terhadap mata pelajaran PAI. Salah satu penyebabnya adalah siswa selalu merasa bahwa pembelajaran PAI 
materinya tidak menarik terutama bagi mata pelajaran yang bersentuhan dengan ayat-ayat al-Qurān karena siswa tersebut tidak pandai membaca alQurān. Kemudian metode mengajarnya dianggap monoton. Adapun solusi yang ditempuh adalah siswa harus terus diberikan motivasi, berikan pembelajaran tambahan terkait materi pelajaran yang tidak diminatinya. Orang tua harus lebih berperan dalam membantu sekolah terkait dengan materi pembelajaran baca tulis al-Qur'ān di rumah atau di Taman Pendidikan al-Qur'ān (TPQ).

b) Faktor guru yang menjadikan siswa enggan mengikuti proses belajar mengajar terhadap mata pelajaran PAI. Guru adalah salah satu penentu keberhasilan dalam proses pembelajaran. Jika guru tidak pandai menggunakan metode pembelajaran yang tepat, maka siswa akan merasa tidak nyaman menerima materi.

Solusinya adalah guru harus lebih berperan aktif mencari metode mengajar yang diminati oleh siswa, agar siswa tersebut lebih tertarik mengikuti pelajaran khususnya mata pelajaran PAI.

c) Terbatasnya sumber ajar berupa buku, modul, serta sumber bacaan lain yang menjadi sumber bacaan terhadap mata pelajaran PAI. Buku adalah salah satu sumber belajar yang sangat penting dalam mencapai tujuan pembelajaran. Jika buku-buku ajar tidak tersedia, siswa akan sulit mencari reverensi atau materi yang diberikan oleh guru, akibatnya siswa tidak tertarik untuk mengikuti pelajaran.

Solusinya adalah pihak sekolah harus segera menyiapkan bahan ajar,

berupa buku-buku penunjang khususnya buku mata pelajaran PAI.

2. Guru

Kendala-kendala yang dialami guru dalam proses pembelajaran PAI humanistik dengan pendekatan active learning adalah:

a) Terbatasnya kemampuan guru PAI dalam menerapkan metode pembelajaran active learning,

b) Terbatasnya pemanfaatan metode pembelajaran active learning oleh sejumlah guru Pendidikan Agama Islam;

c) Keterbatasan kemampuan guru dalam menguasai materi yang diajarkan karena tidak sesuai dengan kompetensi yang dimilikinya

Dari beberapa pendapat tersebut, maka dapat diambil kesimpulan bahwa solusi yang dapat ditempuh apabila guru Pendidikan Agama Islam mengalami hambatan di antaranya:

1. Guru Pendidikan Agama Islam harus sesering mungkin bertukar pikiran dengan guru lain terkait pembelajaran yang tidak dikuasainya.

2. Guru Pendidikan Agama Islam harus sering mengikuti workshop tentang pembelajaran active learning.

3. Memberikan buku-buku referensi yang berhubungan dengan pembelajaran active learning.

4. Guru harus lebih banyak membaca terkait materi yang akan diajarkan, atau sebelum proses pembelajaran yang diajarkan guru harus lebih menguasai materi yang akan diajarkan, dengan cara mencari referensi, atau bahan ajar terkait materi yang akan diajarkan. 
5. Guru harus lebih giat lagi mempelajari Tekhnologi Informasi baik melalui teman, kursus-kursus, atau melalui internet.

Apabila konsep pembelajaran dipahami oleh setiap guru, maka upaya mendesain pembelajaran bukanlah hal sulit dan menjadi beban, tetapi menganggapnya sebagai pekerjaan yang menantang, jika itu sebuah tantangan maka sorang guru yang baik akan selalu mencari solusi untuk mendapatkan jawabannya. Tidak akan menjadikan dirinya diam dan bingung mau berbuat apa. Disinilah letak tuntutan para guru selalu berinovasi dan berkreasi untuk mendapatkan teori dan metode belajar yang menyenangkan. Salah satu caranya adalah banyak membaca referensi atau buku-buku pembejaran yang menjadi penunjang dalam mencapai tujuan. Setelah menemukan konsep pembelajaran yang cocok, guru akan sadar akan fungsi yang sebenarnya yakni sebagai fasilitator terhadap siswanya.

\section{VI.PENUTUP}

Berdasarkan hasil penelitian dan pembahasan, maka dapat disimpulkan sebagai berikut:

1. Pelaksanaan pembelajaran Pendidikan Agama Islam humanistik dengan pendekatan active learning di MTsN 1 Bombana telah dilaksanakan sejak tahun 1978 sekolah ini didirikan sesuai dengan tuntutan pendidikan yang telah di programkan oleh pemerintah. Seiring bergantinya kurikulum pendidikan, pembelajaran PAI humanistik dengan pendektan Active Learning terus dikembangkan. Karena Pendidikan identik dengan kehidupan maka proses pembelajaran di MTsN 1 Bombana telah melaksana proses pembelajaran Agama Islam Humanistik dengan tujuan utamanya memanusiakan manusia, mengajarkan kepada peserta didik apa arti dari kehidupan melalui pendidikan agama Islam.

2. Hasil Pembelajaran Pendidikan agama Islam humanistik dengan pendekatan active learning di MTsN 1 Bombana Peserta didik sebagai pelaku utama yang memaknai proses pengalaman belajarnya sendiri. Diharapkan peserta didik dapat memahami potensi diri, mengembangkan potensi dirinya secara positif dan meminimalkan potensi diri yang bersifat negatif. Dengan dibekalinya Ilmu pendidikan Agama peserta didik di madrasah ini memiliki disiplin dan kerja keras untuk melaksanakan setiap tugas yang diberikan oleh guru. Ini menjadi modal yang cukup baik dan berpengaruh besar pada kemadirian, rasa ingin tahu, gemar membaca serta kreativitas peserta didik.

3. Pembelajaran Pendidikan Agama Islam humanistik dengan pendekatan active learning di MTsN 1 Bombana, tidak selamanya berjalan mulus seperti yang diharapkan, terutama saat sedang terjadi proses pembelajaran. Penerapan proses pembelajaran pendidikan agama Islam humanistik dengan pendekatan active learning tentu tidak terlepas dari berbagai kendala yang dihadapi baik dari siswa maupun dari guru itu sendiri. Kendala tersebut antara lain kurangnya minat siswa untuk mengikuti pelajaran Agama, kurangnya sarana penunjang pembelajaran, terbatasnya pengetahuan tentang metode pembelajaran active learning oleh sejumlah guru pendidikan agama Islam, kurangnya pemahaman siswa tentang materi yang disampaikan, sarana 
pembelajaran yang kurang memadai, Kurangnya pemanfaatan media pembelajaran oleh sebagian guru. Dari kendala tersebut, terus dicarikan solusi pemecahannya agar dapat teratasi dengan baik diantaranya: siswa harus terus diberi motifasi belajar, dipenuhinya sarana pembelajaran, pemberian kesempatan kepada tenaga guru untuk mengikuti berbagai kegiatan pengembangan diri berupa kegiatan workshop dan lain sebagainya.

Implikasi dari penelitian ini adalah: 1) Pembelajaran PAI humanistik dengan pendekatan active learning, perlu dikembangkan terutama terkait implementasi pola pembelajaran PAI yang humanis tersebut; 2) Metode Pembelajaran PAI dengan pendekatan active learning harus lebih variatif agar siswa tidak merasa merima pelajaran dengan metode yang monoton.3) Hasil pembelajaran PAI humanistik dengan pendekatan active learning, harus terpenuhi tiga ranak penbdidikan di lima mata pelaran PAI yakni: ranah kognitif, ranak afektif dan ranah psikomotor. 4) Partisipasi orang tua pada kegiatan proses pembelajaran hendaknya sejalan dengan program pembelajaran yang diterapkan di sekolah terutama dalam pembelajaran PAI,.agar program pembelajaran tercapai sesuai yang diinginkan. 


\section{DAFTAR PUSTAKA}

Ary, Donald. et al. Pengantar penelitian pendidikan, Surabaya: Usaha Nasional, 2006.

Basri, Agus. Pendidikan Islam sebagai Penggerak Pembaharuan. Cet. I; Bandung: PT. Al Ma'rif, 1984.

Dimyati, Mudjiono. Belajar dan Pembelajaran. Jakarta: PT. Rineka Cipta, 1999.

Echols, John M. dan Hassan Sadhily. Kamus Inggris Indonesia Jakarta: Gramedia, 1998.

Sahaka Emporium, Pendekatan Pembelajaran Humanistik, http://sahaka.multiply.com/journal/item/10/Pendekatan_Pembelajaran_Hu manistik, (diakses tanggal 10 September 2017.

Esa, Burhanuddin, dan Nur Wahyuni. Teori Belajar dan Pembelajaran. Yogyakarta: Ar-Ruzz Media, 2010.

Goble, Frank G. Mazhab Ketiga Psikologi Humanistik Abraham Maslow, A. Supratiknya, Yogyakarta: Kanisius, 1987.

Moleong, Lexy J, Metodologi Penelitian Kualitatif, Jakarta: PT. Remaja Rosdakarya, 2014.

Jainuri, Ahmad. "Membangun Karakter Pendidikan Muhammadiyah Yang Holistik, Edukasi. 1 April, 2010.

Rahmahana, Ratna Syifa. Psikolohi Humanistik dan Aplikasinya dalam Pendidikan, El-Tarbawi: Jurnal Pendidikan Islam (http://Journal.Uji.ac.id/), diakses 23 Maret 2012.

Soemanto, Wasty. Psikologi Pendidikan. Jakarta: PT. RajaGrafindo Persada, 1998.

Sugiharto, Bambang. Humanisme dan Humaniora, Ed. II: Bandung: Pustaka Matahari, 2013.

Sugiyono, Sudarwan. Metode Pnelitian pendidikan, Pendekatan Kualitatif, kuantitatif dan $R \& D$. Cet. XIX. Bandung: Alfabeta, 2014.

Sukmadinata, Nana Saodah. Metode Penelitian pendidikan. Bandung: Remaja Rosda Karya, 2007.

Susilo, Herawati dkk. Penelitian Tindakan Kelas Sebagai Sarana Pengembangan Keprofesionalan Guru Dan Calon Guru. ed. Setiyono Wahyudi, dkk, Malang: Bayumedia, 2008. 
Zaini, Hisyam, dkk. Strategi Pembelajaran Aktif. Yogyakarta: Pustaka Insan Madani, 2008.

Zuhairini, Metodologi Pembelajaran Pendidikan Agama Islam. Malang: UIN Press. 2004. 